\title{
Implications of post-translational modifications of IRF7 on pDC IFN-alpha response
}

\author{
M Griesbeck*, E Doyle, RJ Lindsay, J Boucau, S LeGall, M Altfeld, JJ Chang \\ From AIDS Vaccine 2012 \\ Boston, MA, USA. 9-12 September 2012
}

\section{Background}

We previously showed that plasmacytoid dendritic cells (pDCs) derived from females can produce significantly more IFN-alpha in response to HIV-1 and HIV-1-encoded TLR7/8 ligands than pDCs derived from males, resulting in stronger secondary activation of CD8+ T cells (Meier et al., Nat Med 2009). Given the crucial role of interferon regulatory factor 7 (IRF7) in the regulation of type I IFN production by $\mathrm{pDCs}$, the goal of the current study was to investigate its impact on the observed differences.

\section{Methods}

Fresh PBMC were isolated from HIV-1-negative subjects enrolled at Massachusetts General Hospital and stimulated by either CL097 (synthetic TLR7 ligand) or AT-2 inactivated HIV-1. Phosphorylation levels of proteins involved in the TLR7 pathway including IRF7 were measured in pDCs by phospho-flow cytometry at baseline and at different time-points after TLR7 stimulation. The kinetics of IRF7 modifications in the TLR7 pathway were confirmed using mRNA expression of IFN-alpha.

\section{Results}

Baseline levels of phosphorylated IRF7 were found to be similar between males and females. However we observed faster phosphorylation kinetics of IRF7 in females than in males using flow cytometry with phospho-IRF7 peaking in females at 20 min post-stimulation and males at $30 \mathrm{~min}$.

\section{Conclusion}

These data indicate that sex differences in the kinetics of IRF7 phosphorylation might account for described higher IFN-alpha production upon TLR7 stimulation in females, providing new insights into the mechanisms underlying

Ragon Institute of MGH, MIT and Harvard, Charlestown, MA, USA faster HIV-1 disease progression in females compared to males after controlling for viral load (Farzadegan et al., Lancet 1998).

Published: 13 September 2012

\section{doi:10.1186/1742-4690-9-S2-P176}

Cite this article as: Griesbeck et al:: Implications of post-translational modifications of IRF7 on pDC IFN-alpha response. Retrovirology 20129 (Suppl 2):P176.
Submit your next manuscript to BioMed Central and take full advantage of:

- Convenient online submission

- Thorough peer review

- No space constraints or color figure charges

- Immediate publication on acceptance

- Inclusion in PubMed, CAS, Scopus and Google Scholar

- Research which is freely available for redistribution
C Biomed Central

\section{Biomed Central}

